уровне алгоритма работы драйвера.

Список литературы:

1. Емельянов А.В. Шаговые двигатели: учеб. пособие / А.В. Емельянов, А.Н. Шипин / ВолГТУю. - Волгоград, 2005.

\title{
Экологическая проблема переработки гальванических элементов в России
}

\author{
Иванов М.Н., студент, \\ Технический институт (филиал) \\ Северо-Восточного федерального университета, г. Нерюнгри \\ E-mail: fiast2008@yandex.ru
}

Научный руководитель: к.т.н. доцент Шабо К.Я.

Ни для кого не секрет что гальванические элементы заняли важное место в нашей повседневной жизни. Из определений мы все знаем, что гальванические элементы источник электрической энергии, полученный при взаимодействии двух металлов, или оксидов в электролите, которое приводит к возникновению электрического тока в замкнутой цепи. Но не многие из нас, задумывались о вреде, который несет каждый отработавший элемент. Свинец, кадмий, ртуть, никель и щелочи на их основах это только небольшой состав обычной батарейки, а если взять промышленный аккумуляторы и другие элементы, там вредных соединений и металлов в разы больше.

Так что же происходит после того как вы не задумываясь выбросили батарейку в окружающую среду? После выбрасывания металлическое покрытие элемента подвергается коррозии, после этого тяжелые металлы и их оксиды попадают в почву и грунтовые воды, от которых питаются реки, озера и другие водоемы. Один из опасных элементов ртуть имеет свойство накапливаться в живых тканях организма и попадает в основном в организм человека все из тех же вод и растений, выращенных на зараженной земле. То есть многие и не задумываются, как вредят сами себе.

По статистике в каждом городе-миллионнике в год набирается от 1 до 3 тысяч гальванических элементов в год (это не считая предприятия и их отходы). Вред от этих отходов просто колоссальный и растет с каждым днем.

Но как же тогда их утилизировать, может сжигать? Нет, это недопустимо, так как при сжигании все токсичные элементы и материалы попадут в атмосферу, которая и так ежесекундно загрязняется. Тогда обратимся за помощью к другим государствам, как у них происходит процесс переработки. 


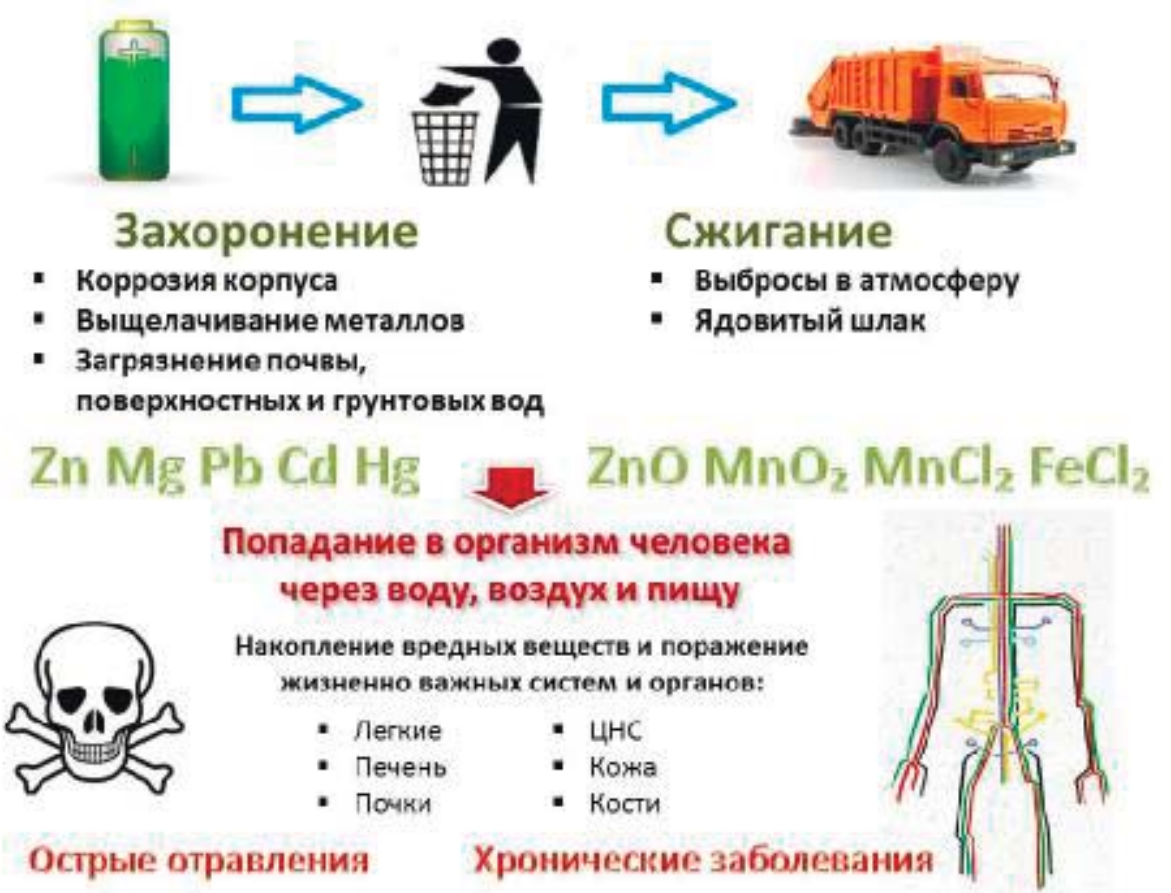

Лидером по переработки являются страны:

1) Европейского союза: 25-45\% переработки всех химических источников тока (ХИТ);

2) США: около 60\% переработки всех ХИТ;

3) Австралия: примерно 80\% переработки всех ХИТ.

Переработка все ХИТ в этих странах является обязательной и с 26 сентября 2008 года все гальванические элементы, которые подлежат обязательной утилизации, маркируются специальным символом, на самом элементе или же на упаковке.

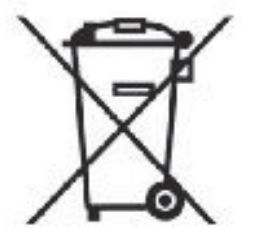

Так откуда такой высокий процент, давайте разберемся вместе. Итак, как было уже сказано выше все эти страны обязует закон о переработки. Далее, так же не будет новостью о размещение пунктов приема этих элементов в перечисленных странах. Так же, страны мотивируют своих жителей, например, при производстве батареек Евросоюзе в их стоимость уже закладывается процент на утилизацию, и покупателей в магазине, сдав старые элементы, получает скидку на новые элементы. Сданное перерабатывается и алгоритм повторяется. Лидером этого процесса является Бельгия и Великобритания, 50\% элементов питания отправляется на переработку. А что касается Австралии, жителей мотивируют денежными выплатами при определенном количестве сданных источников тока. Все типы гальванических элементов, выпускаемых в Европе, могут быть переработаны независимо от того подвергаются ли они перезарядки или нет. После сбора батареи сортируются, и далее отправляются на определенный завод по переработке. Т.е. переработкой занимаются сеть заводов изготовителей. Например, щелочные батареи отправляются в Великобританию, а никель-кадмиевые - во Францию. В Европе существует сеть из 40 предприятий, занимающихся переработкой.

США в 2013 году была запущена новая волонтерская кампания по утилизации гальванических элементов. В ней помимо привлечения волонтеров на сбор 
отработавших батареек, было исполнено ряд мер, которые изменили работу компаний. Так дистрибьютеры и продавцы теперь обеспечивают сбор и переработку источников тока, извлекая при переработке все компоненты, которые можно повторно использовать, а компании-производители платят за работу, по сбору, обработке и утилизации.

В Австралии ежегодно утилизируется 70 тысяч тонн свинцово-кислотных автомобильных аккумуляторов. В городе Вуллонгонг (рядом с Сиднеем) действует завод Auszinc, занимающейся утилизацией бытовых батарей. Элементы, которые не могут быть переработаны в Австралии, экспортируется для утилизации на Европейский союз.

А теперь вернемся домой, в Россию, теперь мы можем понять, почему переработка этих отходов так не популярна у нас. Во-первых, пункт приема даже обычных батареек придется поискать даже в столице нашей Родины, что уж говорить о других городах. Во-вторых, законодательством нашей страны не обуславливается обязательная утилизация отработавших элементов. В-третьих, даже если будут решены две проблемы, заводов по переработки батарей на данный момент существует всего один, но о нем чуть позже. В-четвертых, вряд ли наше с вами государство, как то будет идти к нам на встречу и стимулировать нас к сбору и сдаче этих отходов, скорее всего оно обложит нас налогами. По этим признакам мы можем сделать вывод, что, скорее всего еще долгое время мы, как обычно, будем выбрасывать использованные батарейки вместе с бытовыми отходами.

Однако были небольшие попытки улучшить ситуацию. Например, в 2004 году, компания ИКЕА начала сбор использованных элементов питания, но была вынуждена прекратить эти действия из-за требований Роспотребнадзора. Музей имени Тимирязева, который принимал батарейки с 2009 года, приостановил прием сырья из-за нехватки места для хранения батареек.

И вот в 2013 году Челябинская компания «Мегаполиресурс» заявляет, что готова утилизировать использованные аккумуляторы со всей России. И компания Media Markt запускает первую акцию по сбору батареек. На тот момент сеть приема использованного сырья объединяла 66 магазинов Media Markt в 30 городах России. В рамках этой акции было собрано более 300 тысяч (7 тонн) элементов. Несомненный успех обеспечен и поэтому эту акцию продлевают до 2015 года, появляются новые партнеры в лице МТС и ИКЕА. Положительный эффект наблюдается в заинтересованности других компаний, которые тоже хотят внести свою долю в переработку. К концу 2015 года было собрано около 15 тонн, темпы не падают, открыты сети по приему в новых городах - Красноярске, Йошкар-Оле, Петрозаводске.

Теперь перейдем к процедуре утилизации, с открытием перерабатывающей линии на Челябинской компании «Мегаполиресурс» встал вопрос, как правильно перерабатывать эти элементы. На настоящий момент существует 6 основных этапов:

1) Ручная сортировка, распределяет изделия по размеру, виду и назначению;

2) Ленточным конвейером доставляются элементы питания в дробилку, для измельчения;

3) Измельченное сырье попадет под магнитную ленту, где происходит отделение крупных элементов от мелких;

4) Крупные элементы снова подвергаются дроблению и отделению от железа;

5) Полученная масса содержит электролит, идет процесс нейтрализации;

6) В результате гидрометаллургических технологий сырье разделяется на 
отдельные компоненты и упаковывается.

Таким образом, удается достичь КПД в 80\%. Разработчики программы утверждают, что это на 20\% лучше, чем за рубежом.

А как работает сама программа сбора? По договоренности с «Мегаполиресурс» компании по сбору, должны вывозить батарейки не реже, чем раз в полгода. Сама инфраструктура построена так, чтобы всем участникам цепочки было удобно. В торговом зале каждого гипермаркета сети стоит розовый контейнер, который вмещает около 20 кг батареек. На складе магазина есть еще один ящик, рассчитанный уже на 400 килограммов. В него регулярно пересыпают содержимое маленького контейнера, и, когда он заполняется, специалист склада запечатывает бокс и звонит в «Мегаполисресурс». С завода приезжает машина, которая забирает батарейки. И так по всем городам России.

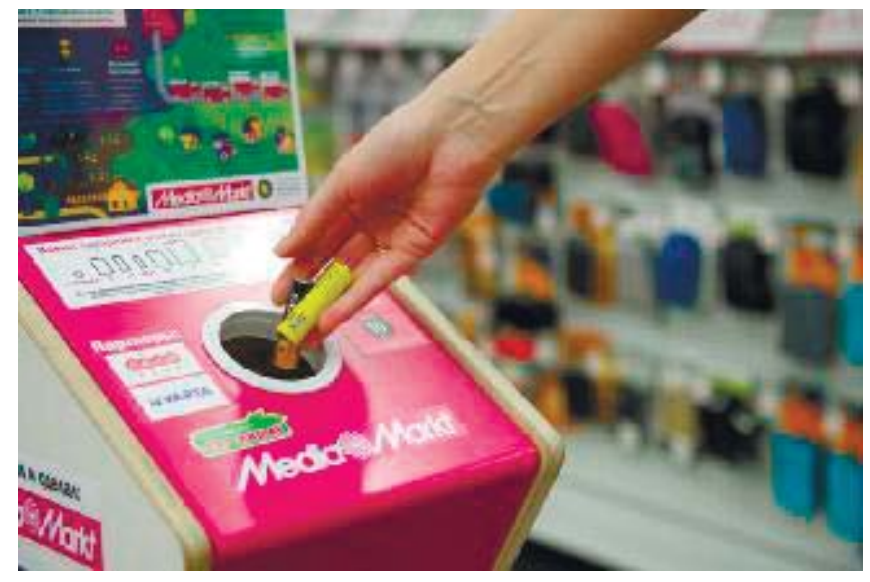

Вообще эта программа, как говорят сами разработчики, не направлена на получения дохода с переработки. Речь идет не о выгоде, а об уменьшении ущерба для экосистемы. Стоимость сырья полученного после переработки, не покрывает расходов по логистики. Средняя цена установилась на отметки в 110 рублей за транспортировку и переработку килограмма гальванических элементов.

На сегодняшний день компания «Мегаполисресурс» работает в штатном режиме, данная программа по утилизации окупается тем, что Челябинский завод имеет основные направления в работе:

-утилизация оргтехники, утилизация электронного лома, утилизация компьютерной техники (мониторы, ЭЛТ и ЖК, системные блоки, клавиатуры, мыши);

-переработка фотоотходов: фиксажи, рентгеновская пленка, пленки с фотовывода и СТР;

-переработка отходов ювелирной промышленности;

-переработка технологических отходов, содержащих драгоценные металлы;

-переработка автомобильных и промышленных катализаторов;

-переработка отходов нефтепродуктов переработка полимеров.

Открыть бизнес, основанный на переработке вредящих экологии отходов, сложно так как низкая развитость данной отрасли. Переработка требует значительных финансовых вложений, которые маловероятно окупятся с продажей вторсырья, поэтому данная программа нуждается в государственном финансировании. Но бедующее не за горами, так что переработка и сбор гальванических элементов выйдут на новый уровень, как и другие отрасли нашей страны. Нам в свою очередь можно попробовать запустить похожую акцию по сбору, и сделать нашу экосистему чуточку лучше. 
Список литературы:

1. Утилизация батареек в России и мире URL: https://ria.ru/spravka/20131121/971073902.html [электронный ресурс]. Дата обращения 11.03.20017

2. Правильная утилизация батареек URL: https:/geektimes.ru/post/158299/ [электронный ресурс]. Дата обращения 15.03.20017

3. Как в России появился первый завод по переработке батареек URL: http://recyclemag.ru/article/kak-v-rossii-pojavilsja-pervyj-zavod-po-pererabotke-batareek [электронный ресурс]. Дата обращения 15.03.20017

4. Правильная утилизация батареек URL: http://vtorothodi.ru/pererabotka/pravilnayapererabotka-batareek [электронный ресурс]. Дата обращения 20.03.20017

\title{
Особенности экосистем в энергетической безопасности арктических энергозон Якутии
}

\author{
Мартынюк П.П., студент, \\ Технический институт (филиал) \\ Северо-Восточного федерального университета, г. Нерюнгри \\ E-mail: martynyuk.apollinariya@mail.ru
}

\section{Научный руководитель: к.т.н., доцент Киушкина В.P.}

Состояние энергетической безопасности говорит о состоянии экосистем, так как ее влияние прямо пропорционально влияет на экологическую безопасность окружающей среды. Как энергетическая безопасность влияет на состояние экосистем, так и экосистемы должны влиять на энергетическую безопасность. Россия слишком большая страна для того чтобы делать общие экологические требования к объектам энергетики на всей территории. Рекреационные возможности северных территорий малы, и темп обновления практически нулевой. Для соблюдения особенностей экосистем необходимо разработать специфичные экологические требования к объектам энергетики для каждой экосистемы отдельно, что позволит в значительной степени уменьшить губительное воздействие выбросов в различных климатических зонах.

Особенности экосистем в составе энергетической безопасности - это неповторимая биота с свойственной ей темпом микробиологического обновления в слиянии с объектами энергетики полностью соответствующими экологическим и энергетическим стандартам.

В мае 2014 года Президент Российской Федерации Владимир Путин подписал указ № 296, который определил сухопутные территории Арктической зоны России [1]. 